\title{
EFFECTS OF PUMPKIN (CUCURBITA MOSCHATA DURCH) SEED POWDER ON BLOOD GLUCOSE LEVEL IN STREPTOZOTOCIN-INDUCED MICE
}

\author{
NOVARIANTI MARBUN*, RUTH MAYANA RUMANTI
}

Faculty of Pharmacy, Helvetia Institute of Health, Medan, Indonesia. Email: novariantimarbun11@gmail.com

Received: 24 April 2019, Revised and Accepted: 01 June 2019

\begin{abstract}
Objective: The aim of this research is to evaluate the antidiabetic effect of pumpkin seed powder in streptozotocin (STZ)-induced diabetic mice.

Methods: Pumpkin seed was used in seed powder suspension form and then evaluate the phytochemical screening and induced diabetic mice using STZ.

Results: The phytochemical screening showed that pumpkin seed powder has various of phytochemical compounds. The pumpkin seed powder (dose level 100,150 , and $200 \mathrm{mg} / \mathrm{kg} \mathrm{bw}$ ) showed a significant reduction of blood glucose.
\end{abstract}

Conclusions: Pumpkin seed powder significantly decreases blood glucose level in STZ-induced mice.

Keywords: Diabetes mellitus, Streptozotocin, Pumpkin, Powder, Seed, Mice.

(C) 2019 The Authors. Published by Innovare Academic Sciences Pvt Ltd. This is an open access article under the CC BY license (http://creativecommons. org/licenses/by/4. 0/) DOI: http://dx.doi.org/10.22159/ajpcr.2019.v12i8.33730

\section{INTRODUCTION}

Diabetes mellitus (DM) is a complex chronic condition that is a major source of poor health throughout the world. This situation is an endocrine disorder that affects various systems in the body. Initially, this metabolic disease begins with glucose insufficiency that causes insulin resistance; as a result, the body fails to maintain glucose homeostasis so that occurs glucose intolerance [1].

DM greatly affects human life, regardless of its socio-economic profile and geographical location; therefore, it is important to limit the surge in diabetes and its complications. Many patients who use alternative therapies such as herbal medicines that are familiar in developing countries because of the relatively lower side effects compared to conventional antidiabetic drugs [2].

One of the plants used as ingredients for traditional medicine is pumpkin (Cucurbita moschata). Pumpkin has many benefits; this is because there are many nutrients in it. Pumpkin has long been consumed by the public as a daily food in various processed forms such as being steamed, rejected, boiled, and steamed [3]. In the flesh of pumpkin contains active compounds such as saponins, tannins, and flavonoids. According to Novarianti [4], extracts of pumpkin seed also contain flavonoids, saponins, tannins, and triterpenoids-steroids. Pumpkin is a traditional vegetable in many countries and is believed to have a lot of health benefits such as anticancer, antioxidant, antihyperlipidemic, and antimicrobial [5-8]. It is not known whether the active substance was more abundant in the extract form. To get all the active substances, pumpkin seed powder was used in this study. The aim of this study was to evaluate the antidiabetic effect of pumpkin seed powder in the streptozotocin (STZ)-induced mice.

\section{METHODS}

Plant collection and preparation

Fresh pumpkin was collected from the local area of Medan (North Sumatera, Indonesia) and authenticated by the Indonesian Institute of Sciences: Research Center for Biology. The seeds of pumpkin were collected, washed, dried, and mashed into the powder. The powder was suspended in sodium carboxymethyl cellulose (CMC) $0.5 \%$.

\section{Preliminary phytochemical screening}

Phytochemical screening was carried out pumpkin seeds powder included examining the chemical secondary metabolites of alkaloids, flavonoids, tannins, triterpenoids, and steroids. The preliminary phytochemical screening was using widely used methods [9-12].

\section{Preparation of animals}

Healthy adult male mice (20-35 g body weight) were obtained from the animal house of Faculty of Pharmacy, University of Sumatera Utara. Mice were housed in a polycarbonate cages in a room with $12 \mathrm{~h}$ day-night circle. They were fed on a standard pellet diet and water ad libitum. The study was approved by Animal Research Ethics Committees (AREC) of University of Sumatera Utara (AREC Reg. No:796/KEPH-FMIPA/2016) and the experiments were conducted according to the ethical norms and AREC guidelines.

\section{Experimental design}

The diabetic mice were induced in overnight fasted mice by a single intraperitoneal injection of $55 \mathrm{mg} / \mathrm{kg}$ of STZ, freshly dissolved in citrate buffer ( $\mathrm{pH} 4.5$ ). After 3 days of STZ injection, mice with fasting glucose above $200 \mathrm{mg} / \mathrm{dl}$ were considered as diabetic and included in the study (Marbun, 2017). The mice were divided into six groups; each group consists of five mice. The groups were administered with sodium CMC $0.5 \%$ (control group):

Table 1: Phytochemical screening result of pumpkin seed powder

\begin{tabular}{lll}
\hline No & Phytochemical compounds & Result \\
\hline 1 & Alkaloids & Negative \\
2 & Flavonoids & Positive \\
3 & Saponins & Positive \\
4 & Tannins & Positive \\
5 & Triterpenoid/Steroids & Positive \\
\hline
\end{tabular}


Table 2: Effect of pumpkin seed powder seed on blood glucose level in diabetic mice

\begin{tabular}{lllllllll}
\hline Group & \multicolumn{7}{l}{ Blood glucose level $(\mathbf{m g} / \mathbf{d l})$} \\
\cline { 2 - 8 } & $\mathbf{0}$ h & $\mathbf{3}^{\text {rd }} \mathbf{d a y}$ & $\mathbf{5}^{\text {th }} \mathbf{d a y}$ & ${\mathbf{7}^{\text {th }} \text { day }}^{\mathbf{9}^{\text {th }} \mathbf{d a y}}$ & $\mathbf{1 1}^{\text {th }} \mathbf{d a y}$ & $\mathbf{1 3}^{\text {th }}$ day & $\mathbf{1 5}^{\text {th }}$ day \\
\hline I & $84 \pm 5.34$ & $86 \pm 3.92$ & $89.67 \pm 3.54$ & $86.67 \pm 5.81$ & $87.33 \pm 5.60$ & $87 \pm 3.93$ & $88 \pm 6.09$ & $89.06 \pm 6.37$ \\
II & $303 \pm 3.92^{*}$ & $311.3 \pm 6.53^{*}$ & $311 \pm 3.93^{*}$ & $317.33 \pm 3.89^{*}$ & $322 \pm 4.17^{*}$ & $329.3 \pm 4.51^{*}$ & $329.33 \pm 4.46^{*}$ & $328.66 \pm 5.81^{*}$ \\
III & $300 \pm 3.1$ & $217.6 \pm 4.3^{* *}$ & $154.3 \pm 4.13^{* *}$ & $127.6 \pm 4.17^{* *}$ & $116.67 \pm 3.92^{* *}$ & $108.67 \pm 6.51^{* *}$ & $103.33 \pm 2.25^{* *}$ & $100.67 \pm 6.09^{* *}$ \\
IV & $309 \pm 10.85$ & $262.67 \pm 1.47^{* *}$ & $223.33 \pm 3.89^{* *}$ & $162 \pm 6.5^{* *}$ & $122 \pm 5.34^{* *}$ & $1106.33 \pm 5.34^{* *}$ & $101.67 \pm 3.92^{* *}$ & $90.33 \pm 6.5^{* *}$ \\
V & $311 \pm 3.1$ & $241.33 \pm 5.37^{* *}$ & $186 \pm 3.1^{* *}$ & $120 \pm 5.34^{* *}$ & $112 \pm 5.81^{* *}$ & $100.33 \pm 3.92^{* *}$ & $97.33 \pm 5.34^{* *}$ & $87 \pm 2.1^{* *}$ \\
VI & $302 \pm 17.8$ & $232.67 \pm 1.1$ & $165.33 \pm 1.2$ & $108 \pm 1.1$ & $90 \pm 0.68$ & $80 \pm 0.78$ & $75 \pm 3.92$ & $70.33 \pm 6.09$ \\
\hline
\end{tabular}

Values are given as mean \pm SEM for three mice in each group. ${ }^{*} \mathrm{p}<0.001$ diabetic group was compared with normal group. ${ }^{* *} \mathrm{p}<0.001$ was compared with the diabetic group. SEM: Standard error of mean

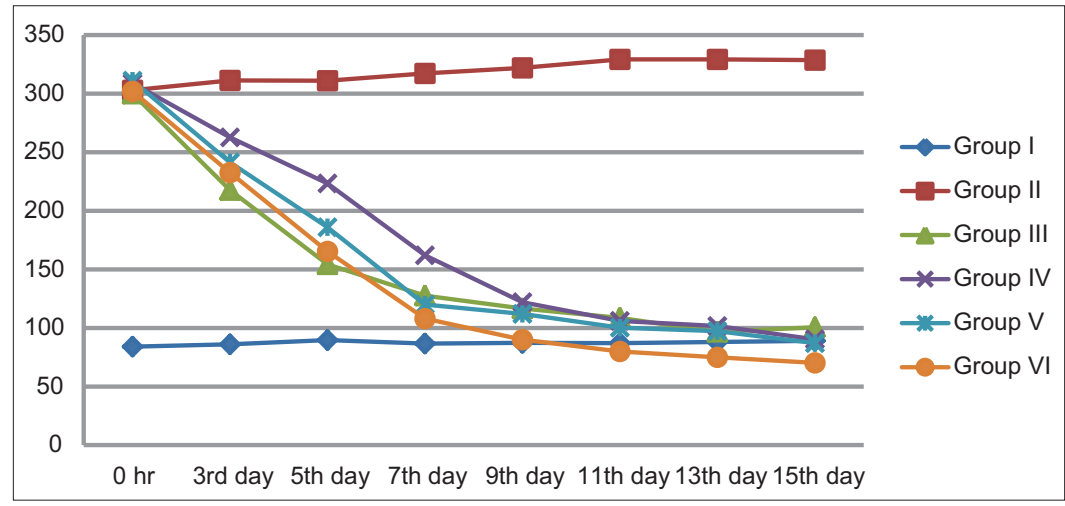

Fig. 1: Effect of pumpkin flesh and seeds ethanolic extract on blood glucose level in diabetic mice (mg/dl)

- Group I: Normal control mice given normal pellet and CMC 0.5\% b/v

- Group II: Negative control (induced by STZ)

- Group III: Mice were induced by STZ and treated with glibenclamide $(0.65 \mathrm{mg} / \mathrm{kg} \mathrm{bw})$

- Group IV: Mice were induced by STZ and treated with pumpkin seed powder $(100 \mathrm{mg} / \mathrm{kg} \mathrm{bw})$

- Group V: Mice were induced by STZ and treated with pumpkin seed powder $(150 \mathrm{mg} / \mathrm{kg} \mathrm{bw})$

- Group VI: Mice were induced by STZ and treated with pumpkin seed powder $(200 \mathrm{mg} / \mathrm{kgbw})$.

The powder of pumpkin seed was given daily through oral way for 15 days.

\section{Statistical analysis}

The glucose levels were determined by triplicates and expressed as mean \pm Standard error of the mean. The significant difference of data between different groups was compared by ANOVA.

\section{RESULTS}

Phytochemical screening of pumpkin flesh and seeds ethanolic extracts

Screening results of pumpkin flesh and seeds ethanolic extract showed different chemical compound in different extract. The results of phytochemical can be seen in Table 1 .

\section{Effect of pumpkin seed powder on diabetic mice}

As shown in Fig. 1 and Table 2, injection of STZ raised the blood glucose compared to normal group, while the glibenclamide and pumpkin seed powder showed significant change compared to the negative control group. Therefore, pumpkin seed powder may act through a similar mechanism to that glibenclamide.

\section{DISCUSSION}

DM is the most common multifactorial chronic disease and known as a very common metabolic disorder of human endocrine systems such as abnormal insulin production or metabolism and chronic hyperglycemia $[13,14]$. STZ is well known for its selective pancreatic islets $\beta$-cell cytotoxicity and has extensively used to induce diabetes in an experimental rat model. It interferes with the cellular metabolic oxidative mechanism. Glibenclamide is often used as a standard antidiabetic drug in STZ-induced moderate diabetes to compare the efficacy of a variety of hypoglycemic compounds or plant extracts. The antidiabetic results indicated that the pumpkin seed powder showed a significant antidiabetic activity, which almost the same as glibenclamide. The possible mechanism might be the potentiating and stimulate of pancreatic secretion of insulin from existing $\beta$-cell [15]. Another possibility is because the flavonoids can protect the DNA from the oxidative damage so that it can resist the problem in $\beta$-cell $[16,17]$.

\section{CONCLUSIONS}

This study demonstrated that pumpkin seed powder can effectively decrease blood glucose level in diabetic mice. Further, clinical studies are required to support this proposal and also to establish the beneficial effects of pumpkin seed on blood glucose levels and insulin resistance.

\section{ACKNOWLEDGMENTS}

This work and publication were supported by Helvetia Institute of Health, Faculty of Pharmacy.

\section{AUTHORS' CONTRIBUTIONS}

All the authors report that they have no conflicts of interest regarding this manuscript.

\section{CONFLICT OF INTERESTS}

None declared.

\section{REFERENCES}

1. Bhat VR, Nayak BS. Evaluation of antidiabetic and hypolipidemic efficacy of various fractions of heartwood of Pterocarpus marsupium (Fabaceae) on alloxan induced diabetic rats. Eur J Med Plants 
$2015 ; 6: 242-8$

2. Ijaola TO, Osunkiyesi AA, Taiwo AA, Oseni OA, Lanrelyanda YA, Ajayi JO, et al. Antidiabetic effect of Ipomoea batatas in normal and alloxan induced diabetic rats. IOSR J Appl Chem 2014;7:16-25.

3. Giacco R, Giulio BD, Vitale M, Cozzoliono R. Functional foods: Can food technology help in the prevention and treatmen of diabetes. Food Nutr Sci 2013;4:827-37.

4. Marbun N. Comparison of Blood Glucose Levels Decrease Effectiveness of Pumpkin Flesh and Seeds toward Diabetic Mice. Thesis, Faculty of Pharmacy, University of Sumatera Utara No. 1-106; 2017.

5. Rumanti RM. Characterization of Simplicia and Chromatographic Analysis of Active Extract Lotus (Nelumbo nucifera Gaertn) which can Reduce Blood Glucose in Mice. Thesis, Faculty of Pharmacy, University of Sumatera Utara No. 1-104; 2017.

6. Lal VK, Gupta PP, Awanish P. Hypoglycemic effect of Kyllinga triceps in STZ induced diabetic rats. J Diabetes Metab 2012;3:1-3.

7. McCarty MF. Nutraceutical resources for diabetes prevention an update. Med Hypotheses 2005;64:151-8.

8. Teugwa CM, Boudjeko T, Tchinda BT, Mejiato PC, Zofou D. Antihyperglycaemic globulins from selected Cucurbitaceae seeds used as antidiabetic medicinal plants in Africa. BMC Complement Altern Med 2013;13:63.

9. Xiaotian C, Changyin W, Jianxin C, Gbago O, Yuanda S. Antibacterial activity of lotus leaves (Nelumbo nucifera) against food-borne pathogens. Am J Biochem Biotechnol 2015;11:11-6.

10. Ditjen PO. Farmakope Indonesia. Vol. 4. Jakarta: Depkes RI; 1995. p. $896-8$.

11. Depkes RI. Materia Medika. Vol. 6. Jakarta: Ditjen POM; 1995. p. 297-307.

12. Farnsworth NR. Biological and phytochemical screening of plants. J Pharm Sci 1966;55:225-76.

13. Bharathi TR, Prakash HS. Comparative evaluation of antidiabetic and antioxidant potency of different extracts obtained from Memecylon species. Int J Pharm Pharm Sci 2017;9:187-91.

14. Priyanka P, Singh R. A systematic review on Indian floral biodiversity as eminent reserves fpr alternative treatment strategy of diabates mellitus. Int J Pharm Pharm Sci 2016;8:10-9.

15. Kar MK, Swain TR, Mishra SK. Antidiabetic activity of Clerodendrum serratum moon leaves un streptozotocin-induced diabetic rats. Asian J Pharm Clin Res 2014;7:260-3.

16. Mujic A, Grdovic N, Mujic I, Mihailovic M, Zivkovic J, Poznanovic G, et al. Antioxidative effects of phenolic extracts from chestnut leaves, catkins and spiny burs in streptozotocin-treated rat pancreatic $\beta$-cells. Food Chem 2011;125:841-9.

17. Acosta-Patiño JL, Jiménez-Balderas E, Juárez-Oropeza MA, Díaz-Zagoya JC. Hypoglycemic action of Cucurbita ficifolia on Type 2 diabetic patients with moderately high blood glucose levels. J Ethnopharmacol 2001;7799-101. 